\title{
Examining the evolution education literature with a focus on teachers: major findings, goals for teacher preparation, and directions for future research
}

\author{
Aaron J Sickel ${ }^{1 *}$ and Patricia Friedrichsen ${ }^{2}$
}

\begin{abstract}
The theory of evolution is the fundamental backbone to the discipline of biology, yet many students possess misunderstandings. The teacher is the most important school-based factor in student learning, and therefore to improve students' understandings of evolution, we must better prepare teachers. The purpose of this paper is three-fold. First, we reviewed empirical research studies focused on K-12 teachers regarding evolution education from 1993 to 2011 with the purpose of identifying major themes of research and corresponding findings. Second, we used our understandings of current findings to inform the development and articulation of five goals for teacher preparation. Third, we discuss implications of this work for teacher preparation initiatives and directions of future research. We found that current evolution education research specific to K-12 teachers falls within four major themes, which collectively inform the development of five goals for preparing teachers to teach evolution. We argue that teachers should: (1) develop content knowledge of evolution; (2) develop understandings of the nature of science related to evolution; (3) develop acceptance of evolution as valid within science; (4) develop knowledge of and strategies for handling the public controversy; and (5) develop pedagogical content knowledge for teaching evolution. Based on our review, evolution courses and professional development initiatives for K-12 teachers should integrate the five goals, with more attention to teaching evolution in the classroom. Investigating the nature of teachers' acceptance of evolution and pedagogical content knowledge for teaching evolution are areas of research in need of continued pursuit.
\end{abstract}

Keywords: Evolution; Goals; Teacher education

The theory of biological evolution is a fundamental framework in biology. It explains the diversity of life, and helps us understand how and why populations change over time. Scientists use the theory of evolution as a framework to address a multitude of real-world dilemmas, such as developing strategies to combat resistant insect populations that are destroying crops (Lenormand et al. 1999), and tracking genetic changes in viruses like the common cold, swine flu, and HIV with the goal of developing vaccines (Zimmer 2001). Evolutionary theory has also helped scientists conserve species that are vital for the survival

\footnotetext{
* Correspondence: sickel@ohio.edu

'Department of Teacher Education, Ohio University, 250 McCracken Hall, Athens, $\mathrm{OH}$ 45701, USA

Full list of author information is available at the end of the article
}

of various ecosystems (Simberloff and Stiling 1996) and develop green technologies (Arnold 2008). Thus, to help students become active citizens in solving global issues (Trefil and Obrien-Trefil 2009), understanding biological evolution is imperative for becoming scientifically literate.

Evolution has consistently appeared in U.S. science education reform documents as a unifying concept for K-12 students to understand, including the Benchmarks for Science Literacy (American Association for the Advancement of Science AAAS 1993), the National Science Education Standards (National Research Council 1996), and the Atlas for Science Literacy (American Association for the Advancement of Science AAAS 2001). In the recently developed framework for the Next Generation Science Standards (National Research Council 2011), evolution 
plays an increasingly prominent role in the K-12 curriculum. By the 12th grade, students are expected to understand the role of genes and mutation in evolution, evidence for evolution, natural selection, speciation, descent from common ancestry, and evolutionary relationships. Evolution is included in the national curriculum in many countries, including the United Kingdom (Cleaves \& Toplis 2007), The Netherlands (Schilders et al. 2009), South Korea (Kim and Nehm 2011), and South Africa (Abrie 2010), among others.

Despite the attention of evolution in reform documents, research demonstrates that $\mathrm{K}-12$ students possess numerous misunderstandings. For example, students tend to think there is little genetic variation within populations (Greene 1990; Rudolph and Stewart 1998), traits change due to an organism's need for it to change (Anderson et al. 2002), and that animals are unique and cannot be the products of change (Evans 2008). Students often view evolution as a purposeful, goal-driven process rather than the accumulation of natural events (Moore et al. 2002; Settlage 1994), and have difficulty grasping the nature of deep time necessary to understand large-scale evolutionary trends (Catley and Novick 2009). Also, students' misunderstandings of the nature of science (NOS) itself and their religious beliefs can interfere with understanding evolution (Dagher and BouJaoude 2005; Moore et al. 2011; Sandoval and Morrison 2003). This leads us to the question, 'How can we improve student understanding and abilities to use evolutionary concepts to explain natural-world phenomena?' To improve student understanding, we must turn our attention to teachers.

The teacher is the most important school-based factor in student learning (Goldhaber and Anthony 2003; National Research Council 2001). K-12 teachers have substantial potential to improve student understandings of evolution, and therefore science teacher educators must think about how to prepare them accordingly. However, as Nehm et al. (2009) point out, there is a lack of consensus on the outcomes of teacher preparation regarding evolution education: 'a critical question facing science teacher educators is how teacher preparation programs can facilitate coordinated conceptual articulation of knowledge, beliefs, and behavior with regard to the teaching of evolution' (p. 1141). Therefore, the purpose of this paper is to examine what we know about teachers' knowledge, beliefs, and practice regarding evolution education, and articulate goals to better prepare K-12 teachers to teach evolution. To do that, we reviewed the empirical evolution literature with the purpose of understanding the different themes of research regarding $\mathrm{K}-12$ teachers. We then summarized the major findings within each theme, and used them to inform the development of five goals for preparing teachers to teach evolution. Last, we argue that these goals should be implemented in preservice teacher education coursework and professional development experiences, and posit directions of future research.

\section{Review: Major Themes of Research on K-12 Teachers and Evolution Education}

In 1992, researchers from across the world met at the Evolution Education Research Conference to discuss and synthesize current findings and suggest future directions for research (Good et al. 1992). The vast majority of studies presented at the conference focused on student understandings. The editors of the conference proceedings specifically highlighted the dearth of research on teachers, and suggested an increased focus on teachers in addition to students. Following up on this directive, we reviewed evolution education studies with a focus on teachers since the proceedings of the conference. Using Education Full Text, ERIC, and SCOPUS databases, we searched for research studies from 1993 to 2011, representing an 18-year span. We used various combinations of the following terms to guide our search: teach, teacher, teaching, evolution, natural selection, science, intelligent design, and creationism. We examined all articles from these searches, and combed through the reference lists to search for additional articles. Using the criteria that the studies had to be data-driven, focused on K-12 teachers, and published in peer-reviewed journals, we arrived at a final count of 52 articles. We then read all of the articles, noting the following: (1) sample population by grade level (elementary, middle school, secondary) and years of experience (preservice, inservice); (2) research methods (survey, case study); and (3) major findings (see Additional file 1). As findings from each study were identified and summarized, we began developing overarching themes of research to help us organize the current knowledge about K-12 teachers and evolution. Using an inductive and emergent approach (Hatch 2002), these themes were revised as more findings were identified to eventually become inclusive of all of the studies. We then synthesized and grouped the major findings into each theme. We found that research on teachers regarding evolution education could be categorized into four themes: (1) teachers' content knowledge of evolution and the nature of science; (2) teachers' acceptance of evolution; (3) teachers' willingness to teach evolution; and (4) teachers' knowledge, beliefs, and practice for teaching evolution to K-12 students. Below, we present the four themes and corresponding findings.

\section{Theme \#1: teachers' content knowledge of evolution and nature of science}

Researchers have examined K-12 teachers' content knowledge of evolutionary concepts, particularly at the preservice level. Evolutionary content knowledge has been measured primarily through the use of multiple-choice questionnaires developed by separate research teams (Abrie 2010; 
Kim and Nehm 2011; Moore and Kraemer 2005; Rutledge and Warden 2000; Vlaardingerbroek and Roederer 1997). Questions focus on factual information related to evolution, for example understanding the age of the Earth or identifying the core concepts associated with natural selection (Rutledge and Warden 2000). Other researchers have studied students' essay responses to natural-world scenarios (Hahn et al. 2005; Jimenez-Aleixandre 1994; Nehm et al. 2009; Zuzovsky 1994). In addition, Crawford et al. (2005) recorded preservice teachers' discussions while completing an online natural selection project, and Nadelson (2009) analyzed preservice teachers' lesson plans following an evolution web-based tutorial. These studies focused on teachers' understanding of natural selection, deep time, and the nature of science.

\section{Teachers' misunderstandings}

Findings related to evolutionary content knowledge revealed that many teachers possessed misunderstandings related to the processes of change in populations, specifically regarding natural selection. Rather than viewing change in populations from a Darwinian perspective, in which organisms best suited for a particular environment are more likely to reproduce and pass their genes to the next generation, many teachers possessed understandings in line with Lamarck's ideas. For example, Zuzovsky (1994) had preservice science teachers answer open-response questions related to pesticide and antibiotic resistance, changes in human populations, and inheritance of traits at the beginning of an evolution course. In one cohort, 19 of 27 teachers used Lamarckian perspectives to answer the questions, including ideas that organisms need to change, modifications are based on use or disuse of traits, and traits acquired through interaction with the environment are inherited. Crawford et al. (2005) found that 18 of 21 preservice teachers entered their methods course with misconceptions similar to Zuzovsky. Studies of practicing teachers reveal similar content knowledge issues regarding natural selection as those with preservice teachers (Jimenez-Aleixandre 1994). Misunderstandings of natural selection were reported by Nehm et al. (2009), who studied 167 beginning pre-certified teachers in New York with an average of two years of teaching experience. There were no significant differences between biology and non-biology teachers with regard to their use of key concepts of natural selection to explain an evolution scenario. Rutledge and Warden's (2000) study of 989 practicing secondary biology teachers in Indiana revealed that $<60 \%$ of teachers responded correctly on questions related to understanding environmental change, reproductive success, process of evolution, and the role of genetic variability in natural selection. In addition to natural selection, 21 preservice teachers' fictitious stories of humanoid evolution in a study by Hahn et al. (2005) also revealed that they did not grasp the nature of deep time needed for evolution to occur.

A few researchers have investigated teachers' understandings of aspects of the nature of science in conjunction with evolution. Rutledge and Warden's (2000) study revealed that secondary biology teachers had misunderstandings of the goals of science and the tentative nature of scientific knowledge. Other researchers have highlighted teachers' misunderstandings of scientific theories (Jackson et al. 1995) and their view that evolution is 'only a theory' (BouJaoude et al. 2011).

\section{Interventions and content knowledge}

Nadelson's (2009) study of 64 preservice teachers of varying subject area and grade-level concentration revealed that they continued to possess misconceptions of natural selection and the nature of science in their constructed lesson plans following a 30-minute web-based tutorial. However, two studies suggest that an evolution course improved teachers' understanding. The teachers in Nehm and Schonfeld's study (2007) had many misconceptions of natural selection but significantly increased their knowledge at the conclusion of an evolution-specific course. Zuzovsky (1994) also described a constructivist evolution course that allowed preservice teachers to score their original answers to evolution questions at the beginning of the course, and therefore became aware of their misunderstandings.

\section{Summary of major findings}

The major finding regarding teachers' evolutionary content knowledge is that many teachers possess misunderstandings related to natural selection, deep time, and the nature of science similar to their K-12 students. This is in spite of previous coursework in biology or prior research experiences. Moreover, comparing Nadelson's (2009) study regarding a 30-minute tutorial to Nehm and Schonfeld's (2007) study of an evolution-specific course, evidence suggests that one-day interventions are not likely to be as effective at improving teachers' content knowledge when compared to a semester-long course or intensive professional development experience.

\section{Theme \#2: teachers' acceptance of evolution}

The second major theme of research regarding K-12 teachers and evolution education is teacher's acceptance of evolution. Acceptance has been measured primarily through multiple choice questionnaires or surveys with Likert-scale responses (Aguillard 1999; Fowler and Meisels 2010; Kose 2010; Losh and Nzekwe 2011a, b; Scharmann 1994; Shankar and Skoog 1993). Many researchers have used items from Rutledge and Warden's (1999) instrument, the Measure of Acceptance of the Theory of Evolution (MATE) (Abrie 2010; Deniz et al. 2008; Kim and 
Nehm 2011; McCrory and Murphy 2009; Rutledge and Warden 2000; Trani 2004). Other methods used to understand teachers' acceptance of evolution have included interviews (Aguillard 1999; Boujaoude et al. 2011; Goldston and Kyzer 2009) and concept maps (Rutledge and Mitchell 2002). Whereas the construct of evolution content knowledge has been mostly associated with understandings of evolutionary mechanisms such as natural selection, items measuring acceptance of evolution have been typically linked to broader evolution topics, including: (1) evolutionary timeframes ('the Earth is 4 billion years old' Fowler and Meisels 2010); (2) descent from common ancestry ('Over billions of years all plants and animals on earth (including humans) descended (evolved) from a common ancestor (e.g., a one-celled organism)' - McCrory and Murphy 2009); (3) human evolution ('Humans are too complicated to have come to be through natural processes, their existence reflects the will of an intelligent designer' - Losh and Nzekwe 2011a); (4) evidence for evolution ('The available data are ambiguous as to whether evolution actually occurs' - Rutledge and Warden 1999); (5) whether evolution is valid within the scientific community ('Most scientists accept evolutionary theory to be a scientifically valid theory' - Rutledge and Warden 1999); and (6) the relationship between evolution and religious beliefs ('Human beings have developed over millions of years from less advanced forms of life, but God guided this process, including the creation of human beings' - Levesque and Guillaume 2010). Below we discuss the nature of teachers' acceptance, factors associated with acceptance, and the role of interventions with acceptance.

\section{Nature of teachers' acceptance}

A few studies have examined teachers' acceptance of evolution with a direct statement on a questionnaire or survey. Findings indicate that a significant number of teachers are unsure about or do not personally accept evolution. Rutledge and Mitchell's study (2002) of 552 practicing secondary biology teachers in Indiana revealed that $67 \%$ of participants accepted evolution, with $19 \%$ undecided and 14\% not accepting. Abrie (2010) found that only $40 \%$ of 46 secondary preservice teachers in South Africa accepted evolution, with $12 \%$ of teachers designated as uncertain, and $48 \%$ being rejecters. Kose (2010) found that 30 of 38 Turkish secondary biology teachers rejected evolution. Studies that have used the MATE (Rutledge and Warden 1999) report average teacher scores between 20 (low acceptance) and 100 (high acceptance). Most studies report scores associated with moderate or just breaking into the high levels of acceptance: 50.95 for 132 preservice Turkish teachers (Deniz et al. 2008); 77.59 for 989 practicing biology teachers in Indiana (Rutledge and Warden 2000); and 73.79 for 84 secondary preservice teachers in Korea (Kim and Nehm 2011).

Studies reporting findings that differentiate between acceptance items reveal two themes. First, teachers tend to accept the notion that evolution is valid within the scientific community more than other items (Rutledge and Warden 2000). Aguillard (1999) reported that 84\% of over 300 teachers agreed that evolution has valid scientific foundation. Moore and Kraemer (2005) reported that all 107 of their teacher participants in Minnesota agreed that 'most scientists believe that the modern theory of evolution is scientifically valid, and $88 \%$ personally agreed there is scientific validity to evolution. In contrast, the least accepted items tended to be associated with human evolution. Only 66\% of 307 Texas biology teachers agreed that 'humans are the product of evolution' in a study by Shankar and Skoog (1993), with McCrory and Murphy (2009) reporting 62\% of 112 teachers for a similar item. Human evolution was also the least accepted item in Rutledge and Warden's (2000) study.

Several studies indicate that elementary teachers are less likely to accept evolution when compared to secondary teachers. Levesque and Guillaume (2010) found that 39\% of elementary preservice teachers believed humans were created in their current form $<10,000$ years ago; their acceptance of evolution was lower than the U.S. national average. Other studies comparing grade level revealed lower levels of acceptance for elementary teachers when compared to secondary teachers (Fowler and Meisels 2010; Losh and Nzekwe 2011b).

\section{Factors associated with acceptance}

Our review of empirical studies revealed three primary factors that are associated with teachers' acceptance or lack of acceptance of evolution: (1) religious beliefs; (2) understandings of the nature of science; and (3) biology and evolution coursework. A fourth possible factor, evolution content knowledge, has been shown to have a weak association with acceptance. These are discussed in turn.

The factor most widely associated with acceptance of evolution is personal religious beliefs. Many teachers believe in a supernatural creator and/or subscribe to the teaching of a holy book such as the Bible or Quran. Studies have found negative correlations to exist between acceptance and religious convictions (Abrie 2010; Trani 2004 ) - that is, the stronger the religious conviction, the less likely a teacher will accept evolution. Losh and Nzekwe (2011a, b) examined several variables related to 663 preservice teachers' pseudoscience beliefs. Although their sample included teachers of varying grade-level concentration and subject area, religiosity measures were the largest predictors of the creationism and evolution indices. A fundamentalist view, or exclusivist view, in which teachers believe their religion is the only 'correct' 
view of the world has been found to correlate strongly with lack of acceptance (Losh and Nzekwe 2011b). Kose (2010) reports that $70 \%$ of Turkish secondary biology teachers who rejected the notion that evolution has occurred over millions of years believed in religious accounts literally. Similarly, Levesque and Guillaume (2010) found that $93 \%$ of elementary preservice teachers who believed in the Bible literally rejected evolution. In contrast to teachers with fundamentalist views, Trani's study (2004) of secondary biology teachers in Oregon revealed that teachers with moderate religious convictions did not score significantly different on measures related to understanding or acceptance. However, teachers with moderate convictions often accept some evolutionary topics while rejecting others. Teachers who feel some conflict between their religious beliefs and evolution tend to accept the mechanisms of evolution, but believe there is an ultimate creator or greater purpose to the process (Dodick et al. 2010; Goldston and Kyzer 2009; Meadows et al. 2000; Winslow et al. 2011). Tomczyk and Bugajak (2009) found that $80 \%$ of Polish teachers who believed in an ultimate aim of evolution saw no conflict between religion and evolution because they could reconcile evolution within their teleological viewpoints. Moreover, BouJaoude et al. (2011) found that some Muslim and Christian secondary science teachers in Lebanon felt they could not accept the proposition of human evolution while accepting other aspects.

The second factor associated with teachers' acceptance of evolution is the understanding of the nature of science. A few studies indicate that teachers' understanding of NOS are associated with their religious beliefs (Nehm and Schonfeld 2007; Trani 2004), whereby teachers with strong religious convictions are less likely to perform well on NOS measures. Teachers who do possess more sophisticated understandings of NOS are more likely to accept evolution. Rutledge and Warden (2000) reported a significant association between Indiana teachers' scores on a NOS subscale and acceptance subscale within the same instrument. Rutledge and Mitchell (2002) found a similarly positive correlation in a different Indiana teacher sample, revealing that teachers who had taken a NOS course were more likely to accept evolution.

Several studies document positive correlations between prior biology or evolution coursework and acceptance of evolution. Rutledge and Mitchell (2002) found significant associations between previous credit hours earned in biology and acceptance, with the largest percentage of accepters earning $>40$ undergraduate or graduate biology credits. A significant association also existed between taking an evolution course and accepting evolution, which is supported by Kose's (2010) study as well. In addition, Asghar et al. (2007) found that $71 \%$ of Canadian elementary preservice teachers responded positively to an acceptance item following a basic science course with evolution content, representing a higher percentage of acceptance for elementary majors than what was found in other studies.

Although exposure to biology and evolution coursework seems to be associated with acceptance of evolution, it is less clear whether or not teachers' individual knowledge of evolution content influences acceptance. Rutledge and Warden (2000) report a significant correlation between teachers' scores on a content knowledge instrument and their acceptance score on the MATE (Rutledge \& Warden, 1999). Deniz et al. (2008) also found a significant correlation between Turkish preservice secondary teachers' understanding and acceptance using the same instruments. However, the variable of understanding only accounted for $3.3 \%$ of the variance in teachers' acceptance. Using different measures, Nehm et al. (2009) found a weak association between knowledge and beliefs regarding evolution, and argue that the two are distinct constructs. This supports the notion that improving teachers' understanding of evolution, in and of itself, is unlikely to greatly influence their personal acceptance.

\section{Interventions and acceptance}

A few studies have examined teachers' acceptance during or after some form of an evolution or nature of science intervention. Schrein et al. (2009) described a one-day evolution workshop they developed and conducted for 11 Arizona middle and secondary science teachers. The workshop focused on a number of evolution education topics, including students' misconceptions, resources to teach evolution, acceptance of evolution, legal issues, and standardized testing. Six of the participants' MATE scores improved after the workshop, although two participants' scores decreased. Two other studies investigated teachers' views of evolution as a valid scientific theory during a preservice teacher course. Scharmann et al. (2005) described a middle and secondary science methods course in which they taught NOS in an explicit-reflective manner, highlighting criteria used to evaluate the validity of knowledge claims. During three iterations of the course, they asked preservice teachers to place intelligent design and evolution along a 'scientific to less scientific' continuum. By the third implementation, all six participants placed intelligent design toward the 'less scientific' end of the scale. Through continued iterations of the NOS unit, Smith and Scharmann (2008) examined the nature of conceptual change undergone by three selected cases. These three participants eventually viewed evolution as being more valid than intelligent design, but experienced varying degrees of emotional turmoil. Smith and Scharmann (2008) noted the importance of allowing the science-religion issues to surface naturally and be handled with respect. 


\section{Summary of major findings}

A major finding related to acceptance is that, when directly asked, at least one-third of teachers assert that they do not accept evolution or are undecided, with elementary teachers being less likely to accept evolution than secondary teachers. Teachers are more willing to accept evolution as valid within the scientific community when compared to other items. A significant portion of teachers who accept some aspects of evolution are likely to accept microevolution processes while rejecting the broader, larger-scale aspects (for example, speciation, descent with common ancestry, and the notion that humans are a product of evolution). Two important factors associated with rejecting evolution include teachers' religious beliefs perceived to be in conflict with evolution, and misunderstandings of NOS. Exposure to biology and evolution coursework is positively correlated with acceptance, though the association between an individual teacher's understanding and acceptance of evolution has been shown to be weak. During instructional units of evolution, discussing sciencereligion issues in an up-front manner and explicitly teaching NOS has the potential to help teachers view evolution as scientifically valid.

\section{Theme \#3: teachers' willingness to teach evolution}

The third theme of research addressed the extent to which teachers are willing to teach evolution. Findings related to this theme can be divided into four areas: beliefs about whether evolution or creationism should be included in the curriculum; instructional time allotted for evolution or creationism teaching; factors associated with instructional time; and curricular topics emphasized. Most studies relied on teachers' self-reported answers to survey questions.

\section{Beliefs about including evolution or creationism in the curriculum}

Several studies have asked secondary teachers about their views regarding whether evolution or creationism should be included in the curriculum. Results indicate that a substantial percentage of teachers do not believe evolution is a necessary part of the curriculum, or believe creationism should be taught in conjunction with evolution. Abrie (2010) examined 46 preservice teachers' attitudes toward evolution education following the compulsory inclusion of evolution in the national curriculum of South Africa in 2008. The study revealed that only $42 \%$ believed it should be compulsory, while $44 \%$ believed students should have the option to not attend class during evolution instruction. Kose (2010) found that $84.2 \%$ of Turkish preservice teachers believed both evolution and creationism should be included. Studies in the U.S. report similar findings (Jackson et al. 1995; Shankar and Skoog 1993). In Berkman and Plutzer's (2011) large-scale study of 926 practicing teachers, only $28 \%$ of teachers were strong advocates of teaching evolution, with $60 \%$ of participants advocating for some aspects of evolution to be taught, and 13\% being advocates for teaching creationism or intelligent design. Moreover, Osif's (1997) study revealed that one-third of teachers in Pennsylvania advocated for the teaching of 'creation science,' with no significant difference between science and English teachers. For those teachers who do believe evolution should be included, most do not believe it is a unifying theme in the discipline of biology, and therefore view it as a stand-alone unit. Weld and McNew (1999) report that $57 \%$ of 224 teachers viewed it as a unifying theme, with $47 \%$ of 307 teachers in Shankar and Skoog's (1993) study, and only $28 \%$ in Berkman et al.'s (2008) large-scale study of 939 practicing biology teachers in the U.S.

\section{Instructional time for teaching evolution or creationism}

Findings indicate that teachers spend no more than a few weeks on teaching evolution in the secondary biology curriculum. The most time spent was reported by Donnelly and Boone (2007), in which Indiana teachers spent an average of 14 days. Other studies revealed quicker timeframes; Berkman et al.'s (2008) national survey of 939 teachers revealed an average of 13.7 hours, Rutledge and Mitchell (2002) found that a majority of teachers spent $<7$ days, and the greatest percentage of teachers in Aguillard's (1999) study only spent 2.5 to 5 days. In line with studies on teachers' beliefs about whether creationism should be taught, approximately $20 \%$ to $30 \%$ of teachers selfreported that they included creationism when teaching evolution (Aguillard 1999; Berkman et al. 2008; Moore 2007; Weld and McNew 1999).

\section{Factors associated with instructional time}

Three major factors were discussed in the literature as potentially being associated with teachers' willingness to teach evolution or creationism as well as instructional time allotted in the classroom. These include: (1) understanding and acceptance of evolution; (2) teachers' attitudes toward state and national standards; and (3) evolution coursework.

Two studies reported positive associations between teachers' understanding of evolution and instructional time (Shankar and Skoog 1993; Trani 2004). However, the factor most frequently associated with instructional time in the literature was teachers' acceptance. Trani (2004) investigated the associations among many different variables related to teachers and evolution education, and found the association between acceptance and instructional time to be the second strongest correlation. Several other studies report that teachers who accepted evolution spent more time teaching it in the classroom (Aguillard 1999; Berkman et al. 2008; BouJaoude et al. 2011; Rutledge and Mitchell 2002; Trani 2004). BouJaoude 
et al. (2011) found that eight of nine Lebanese teachers who accepted evolution believed it should be taught. In Aguillard's (1999) study, 43\% of secondary biology teachers in Louisiana who viewed evolution as scientifically valid devoted more than five class periods to evolution instruction, whereas $70 \%$ of rejecters committed less than five class periods.

Another factor associated with teaching evolution is teachers' attitudes and understandings of state standards (Berkman and Plutzer 2011). Donnelly and Boone (2007) developed an instrument to investigate 225 biology teachers' attitudes toward the Indiana state standards and their evolution teaching practices. The results indicate that teachers' attitudes toward the evolution standards were strong predictors of their instructional time for teaching evolution. The teachers found the evolution standards to be useful, particularly to justify their teaching of evolution to administrators and parents. Similarly, six preservice teachers relied on their knowledge of the state curriculum to justify teaching evolution in simulated parent-teacher conferences (Dotger et al. 2010). Other studies report that teachers are less likely to teach evolution if the state or national standards are not clear or leave evolution out (BouJaoude et al. 2011; Goldston and Kyzer 2009). Moreover, a lack of adequate evolution standards could be contributing to the teaching of creationism, as Moore (2004) found that 27\% of 103 biology teachers in Minnesota believed they had the choice to teach creationism in the science curriculum.

Whereas the literature is consistent regarding the associations of acceptance and attitudes toward standards with instructional time, findings regarding the third factor evolution coursework - are less clear. Nehm et al. (2009) did not find a significant association between evolution coursework and advocacy for teaching evolution. Nearly half of 167 science teachers in New York City advocated for teaching creationism. In another study by Nehm and Schonfeld (2007), teachers who increased their content knowledge through an evolution course were not more likely to advocate for teaching evolution. However, Berkman and Plutzer (2011) reported that teachers who were advocates of evolution education were more likely to have taken an evolution course. Other studies support this assertion as well (Aguillard 1999; Donnelly and Boone 2007).

\section{Curricular topics emphasized}

In line with findings regarding teachers' beliefs about what evolution topics should be taught in the curriculum, researchers who asked teachers to report the topics they teach during evolution instruction reveal mostly microevolution processes while leaving out macroevolution. Several studies revealed that teachers emphasized natural selection, mutations, and evidence for evolution while ignoring such topics as speciation, descent from common ancestry, and human evolution (Aguillard 1999; Schulteis
2010; Shankar and Skoog 1993; Tidon and Lewontin 2004; van Dijk 2009).

\section{Summary of major findings}

Findings in the literature indicate that at least one-third of teachers do not advocate for teaching evolution or advocate for teaching some version of creationism in the classroom. In line with the majority of teachers who selectively accept evolution (microevolution but not macroevolution), teachers who do teach evolution in some capacity typically teach natural selection as a stand-alone unit rather than broader evolution topics as a unifying theme. The factor most consistently reported as being associated with willingness to teach evolution is acceptance, whereby teachers who accept evolution are more likely to teach it in the classroom. In addition, developing positive attitudes toward evolution standards at the state and national level seems to support increased instructional time in the classroom.

\section{Theme \#4: teaching evolution to K-12 students}

The fourth theme of our review focused on teachers' knowledge, beliefs, or practice regarding the teaching of evolution to K-12 students. In addition to several survey studies (Asghar et al. 2007, Fowler and Meisels 2010; Schulteis 2010; Weld and McNew 1999), a few studies incorporated qualitative data sources and analysis (Cleaves and Toplis 2007; van Dijk 2009; Veal and Kubasko 2003). We discuss this theme in terms of teachers coping with the controversy, knowledge of students' understandings of evolution, and strategies for teaching evolution.

\section{Coping with the controversy}

Studies have documented teachers' perceptions of the controversy related to teaching evolution. Many teachers report feeling uncomfortable with handling the controversial nature of teaching evolution, and are concerned about offending students (Asghar et al. 2007; Weld and McNew 1999). Cleaves and Toplis (2007) found that $20 \%$ of 35 preservice teachers and nearly half of 29 experienced secondary science teachers in the U.K. had encountered challenges from students when teaching evolution. This is potentially exacerbated by social pressure to avoid teaching evolution by administrators and parents (Fowler and Meisels 2010; Schulteis 2010; Veal and Kubasko 2003). Moore and Kraemer (2005) compared survey responses of Minnesota biology teachers from $1995(n=91)$ and 2003 ( $n=107$ ) regarding their teaching of evolution. The percentage of respondents indicating that both parents and administrators applied pressure not to teach evolution increased from 1995 to 2003 (12\% to 25\% for parents and $4 \%$ to $8 \%$ for administrators). As such, a typical strategy for teachers is to avoid any mention of the controversy when teaching evolution (Jackson et al. 1995; Schilders 
et al. 2009). A case study by Oliveira et al. (2011) examined a beginning biology teacher's attempts to deal with the evolution/creationism controversy during a threeweek evolution unit. Although the teacher (Mr. Howe) was polite and maintained a neutral stance to make students feel comfortable, the discussions lacked the intellectual ferment' necessary to help students deeply consider evolution. Their in-depth analysis of the social dimensions of the unit revealed that students were willing to share ideas and opinions, but Mr. Howe missed opportunities to manage these ideas and give credence to the scientific perspective.

\section{Knowledge and beliefs of students' understandings of evolution}

Few studies have examined teachers' knowledge or beliefs about students' understandings of evolution. Two studies reported that not all teachers believe students are capable of understanding evolution (Aguillard 1999; Schulteis 2010). Jimenez-Aleixandre (1994) examined teachers' abilities to analyze 14-year-old students' answers to natural selection scenarios. Both preservice and practicing teachers had difficulties identifying the underlying conceptual difficulties in students' alternative conceptions, for instance a view of evolution as intentional and purposeful. However, two studies reported that teachers possessed knowledge of students' difficulties with evolution. Veal and Kubasko (2003) reported that biology teachers were better able to identify students' misconceptions when compared to geology teachers. van Dijk (2009) interviewed nine German biology teachers who had five or more years of teaching experience, and found that the participants identified many types of preconceptions, including a failure to understand intra-species variation, a goal-directedness view of adaptation, a view of selection occurring on the individual level, and misunderstandings of descent from common ancestry.

\section{Strategies for teaching evolutionary concepts}

Studies with empirical findings related to teachers' knowledge or practice of teaching evolution in the classroom are limited. In a survey of teachers in Oklahoma, 66\% agreed with the National Association of Biology Teachers statement that teaching evolution requires discussion and lab activities (Weld and McNew 1999), yet there is no evidence as to whether they used such strategies. In one study of teachers' practices, Marcelos and Nagem (2011) investigated whether or not 63 Brazilian teachers used Darwin's 'tree of life' analogy to teach the concepts of speciation and large-scale trends in evolution. While 58\% of the teachers reported making some comparisons between evolution and a tree in their instruction, data from other survey items, focus group interviews, and classroom observations indicated that the teachers lacked knowledge of teaching the analogical features of the tree of life representation.

Only two studies in our search explicitly examined the nature of teachers' pedagogical content knowledge (PCK) for teaching evolution - that is, how teachers combined their knowledge of instructional strategies, students' understandings, curricula, and/or assessment for teaching evolution to K-12 students (van Dijk 2009; Veal and Kubasko 2003). As mentioned above, van Dijk (2009) studied experienced teachers' knowledge of students' preconceptions of evolution, and also the extent to which teachers connected that knowledge to instructional strategies. She found that the teachers could identify specific examples for teaching evolution (for example, finches, peppered moths, and dog breeding) but their representations were not always linked specifically to students' misunderstandings. A few studies have indicated that teachers feel a lack of preparedness to teach evolution, and desire more professional development (Asghar et al. 2007; Sanders and Ngxola 2009). Griffith and Brem (2004) found that teachers desired not only access to curricula, but detailed lesson plans:

More than just a list of things to do, they asked for lessons that included narratives that described the experiences and emotions that had accompanied previous implementations of the lessons, provided tips and strategies that helped things move along more smoothly or led to teachable moments, and discussed how the lesson did or did not have a lasting effect on students, the classroom, and the teacher. (p. 805)

Thus, there is evidence suggesting that teachers would benefit not only from interventions aimed at improving content knowledge, but also efforts focused on developing PCK for teaching evolution.

\section{Summary of major findings}

Findings indicate that teachers are unsure how to deal with the controversial nature of evolution in the classroom. The few studies focusing on how teachers teach evolutionary concepts suggest that beginning teachers have difficulties identifying students' misconceptions and both beginning and experienced teachers have difficulties with responding to students' misconceptions with targeted instructional strategies. Moreover, studies report that teachers desire more access to lesson plans and curricula for teaching evolution.

\section{Goals for preparing teachers to teach evolution}

After synthesizing the major findings regarding teachers' knowledge, beliefs, and practice regarding evolution education, we considered how the findings informed specific goals for teacher preparation. Our analysis resulted in five 
goals. In Figure 1, we map the themes of research to the goals they support. We discuss our rationales and articulate each goal in the following section.

\section{Goal \#1: content knowledge}

Several studies report that K-12 teachers possess misunderstandings of evolution similar to the literature on students' misunderstandings (Abrie 2010; Crawford et al. 2005; Hahn et al. 2005; Nehm et al. 2009; Zuzovsky 1994). The research on teacher knowledge suggests that, while not sufficient by itself, strong subject matter knowledge is essential for effective science teaching (Abell 2007). Preservice teachers who have been exposed to evolution instruction in secondary science classrooms are still graduating with misunderstandings. Content knowledge of evolution must therefore remain an explicit goal for teacher preparation. Although scientists do not always find it necessary to distinguish between 'micro'-evolution and 'macro'-evolution, the literature demonstrates that teachers often selectively accept microevolution, while rejecting the broader view of macroevolution. We recommend the following areas be explicitly addressed during teacher preparation (Catley et al. 2005; Freeman and Herron 2001; University of California - Berkeley 2012; Zimmer 2010):

- Mutations as a source of genetic variation

- Mechanisms of evolution - the various ways evolution occurs in nature, including natural selection, sexual selection, and genetic drift. In particular, teachers should understand and be able to use the core concepts of natural selection (genetic variation in populations, struggle for existence, differential reproduction, and heredity of favorable traits - National Research Council 1996, 2011) to explain natural-world phenomena

- Microevolution - observing changes in populations over a relatively short time period (a few generations). Teachers should learn to track genetic changes in populations using Hardy-Weinberg laws of equilibrium

- Speciation - the factors involved and modes by which populations diverge into new species, including geographic isolation, bottlenecking, and hybridization

- Macroevolution - tracking large-scale trends in species over a relatively long period of time (for example, millions of years). Teachers should develop understandings of broader evolutionary concepts, including evidence for evolution, evolutionary timeframes, descent from common ancestry, and phylogenetic relationships among different taxa. Moreover, it would be helpful for teachers to understand how large-scale trends in evolution (macroevolution) represent the culmination of evolutionary processes (microevolution) over time. Thus, it should be a goal for teachers to understand that macroevolution and microevolution are not disconnected concepts

- Evidence for evolution - including biogeography, fossils, DNA analysis, morphological comparisons, and embryology

These topics are identified as important both by scientists (Freeman and Herron 2001; Zimmer 2010) and reform documents (American Association for the Advancement

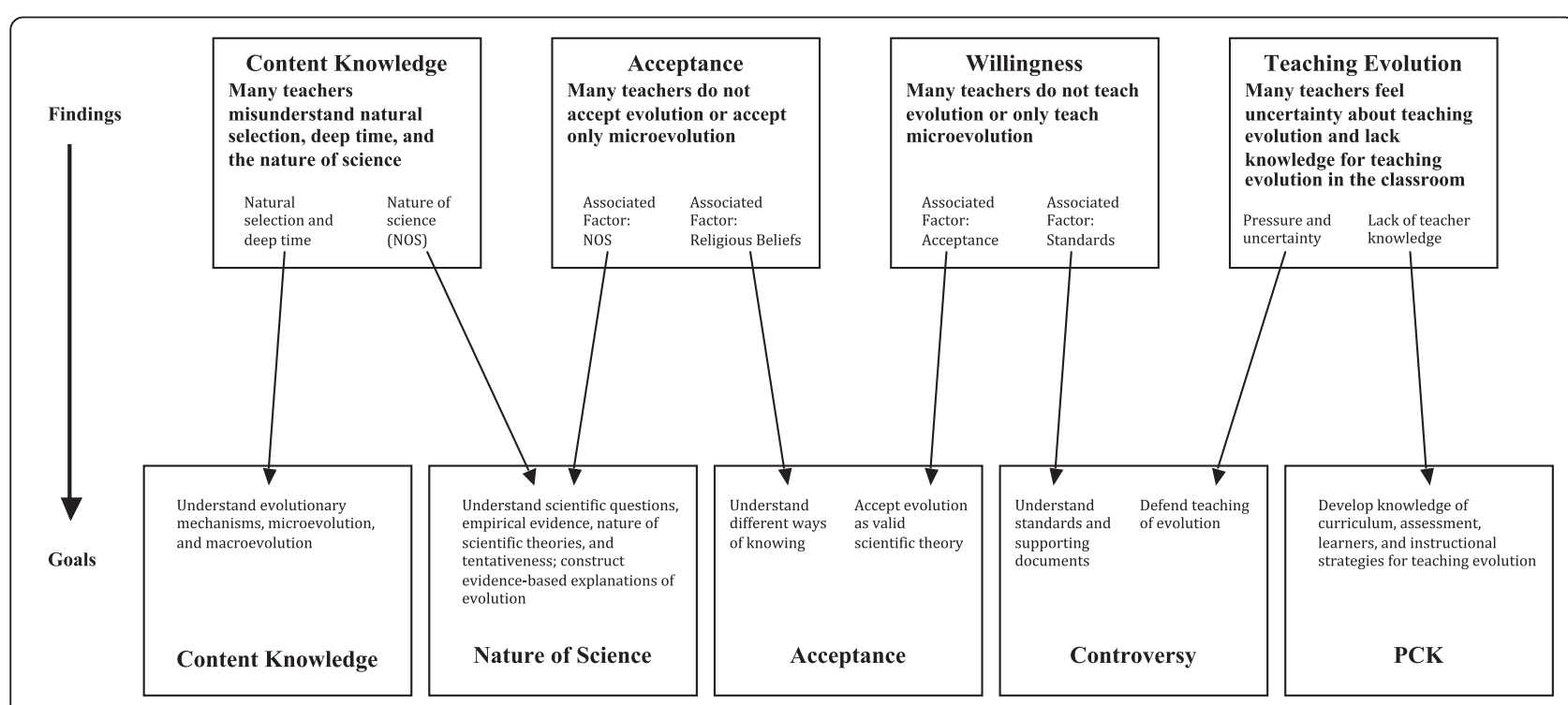

Figure 1 Mapping research findings to goals for teacher preparation. 
of Science AAAS 1993, 2001; National Research Council 1996, 2011). However, secondary biology teachers may learn these topics in more depth than elementary teachers, reflecting the differences in content knowledge expectations in reform documents for different age groups.

\section{Goal \#2: nature of science}

Teachers' understanding of NOS have been shown to correlate with their acceptance of evolution (Rutledge and Mitchell 2002; Rutledge and Warden 2000), which in turn correlates to their willingness to teach evolution. Thus, during instructional units on evolution, we recommend that the following aspects of NOS be explicitly taught (Lederman et al. 2002):

- Nature of Scientific Questions - Science seeks to answer questions related to describing and explaining the natural world

- Empirical Nature of Scientific Knowledge - Scientific knowledge consists of descriptions and explanations derived from humans' inferences of empirical, natural-world data

- Nature of Scientific Theories - Scientific theories are broad-ranging explanations of fundamental aspects of the natural world based upon multiple sources of physical evidence

- Tentativeness of Scientific Knowledge - Scientific knowledge is not static, but rather changes in light of new evidence

Teaching these aspects of NOS could help teachers understand science as a way of knowing by examining the scope and limitations of science in answering certain questions. It could help teachers understand that evolutionary theory is a sturdy collection of principles rather than an untested idea waiting to become a law. In addition, teachers could come to understand that, like all scientific knowledge, evolutionary theory is subject to modification as scientists examine more evidence in the future. To ensure that knowledge of the nature of science related to evolution does not become inert, teachers would benefit from engaging in scientific practices to construct understandings of evolution. For example, preservice teachers in Crawford et al.'s (2005) study analyzed data collected by Peter and Rosemary Grant in the Galapagos Islands regarding a finch population (Reiser et al. 2001). The teachers constructed evidence-based explanations and presented them to the class to understand how the finch population changed over time. Having teachers construct evidence-based explanations to understand evolution and then reflecting on that process will improve their abilities to help future students engage in similar practices.

\section{Goal \#3: acceptance}

Findings from the empirical literature reveal that acceptance of evolution is an important construct for teaching evolution. At least one-third of K-12 teachers in different parts of the world proclaim that they are undecided or do not accept evolution (Abrie 2010; Kose 2010; Rutledge and Mitchell 2002), and acceptance is the construct most consistently associated with willingness to teach evolution and instructional time in the classroom (Berkman et al. 2008; Rutledge and Mitchell 2002; Trani 2004). Thus, teacher education programs must address this problem.

The factor most widely reported as negatively correlated with acceptance is teachers' religious beliefs (Abrie 2010; Losh and Nzekwe 2011a, b; Trani 2004). In particular, teachers who possess an exclusivist view in which there is only one way of knowing the world are likely to reject evolutionary theory (Levesque and Guillaume 2010; Losh and Nzekwe 2011b). Nehm et al. (2009) point out, there is little agreement about whether knowledge and belief change are legitimate goals of evolution education' (p. 1141). While we certainly invite teachers to accept the abundance of data and interpretations that support evolutionary theory as we do, we also concur with other science educators who argue that personal acceptance or belief in evolution should not be the primary goal for teaching evolution to students (National Academy of Sciences 1998; Smith and Siegel 2004; Southerland 2000). However, we argue that developing acceptance of evolution as a valid scientific theory is an appropriate goal for future K12 science teachers. In several studies, teachers selfreported that they accepted evolution as valid within the scientific community (Aguillard 1999; Moore and Kraemer 2005; Rutledge and Warden 2000). Teacher educators and scientists could help teachers further articulate this distinction between accepting evolution as valid within science versus personally accepting evolution. In particular, teachers must have opportunities to understand basic assumptions of different ways of knowing, such as religion and science (Evans et al. 2011). Religions typically rely upon a combination of tenets from holy books and belief in supernatural entities to make claims, whereas science relies upon interpretations of physical evidence to construct explanations of the natural world. In a study by Winslow et al. (2011), Christian college students with biology-related majors were eventually able to reconcile these different ways of knowing, and therefore could accept evolution as a valid scientific theory.

Research indicates that students and teachers need to be able to discuss evolution in a way that does not immediately threaten their religious beliefs (Scharmann 1990, Southerland and Sinatra 2003). For teachers who claim to be creationists, it may be helpful for them to read about the different creationist viewpoints. For example, while conflict exists between young Earth creationism 
and evolution due to a literal interpretation of the book of Genesis, many people find compatibility between theistic creationism and evolution in which a supernatural entity does not directly interfere with the laws of nature (Scott 1997). Upon reflection, some teachers may recognize that their religious beliefs do not interfere with accepting evolution to the extent they originally had anticipated. The work of Scharmann et al. (2005) and Smith and Scharmann (2008) demonstrate that asking teachers to place evolution and other ways of knowing on a 'scientific to less scientific' continuum after targeted instructional units on knowledge claims can help teachers view evolution as scientifically valid. Hermann (2008) refers to such approaches as procedural neutrality, in which teachers are allowed to explore their beliefs and never asked to ascribe to an 'either/or' mentality in which they have to choose between accepting evolution and adhering to religious beliefs. We recommend this approach, with the goal that teachers learn to consider different epistemologies, yet develop acceptance that evolution is valid within the methodologies of science.

\section{Goal \#4: handling the controversy}

While there is little controversy surrounding evolution within the scientific community, it very much persists in the educational arena. Teachers report pressure from various people not to teach evolution or incorporate versions of creationism into their instruction (Moore and Kraemer 2005; Schulteis 2010; Veal and Kubasko 2003). Thus, teachers need to develop knowledge of and strategies for speaking with people who are opposed to evolution education. We recommend that teachers become aware of the following supports for teaching evolution:

- State and national standards - For teachers in states and/or countries in which there are specific evolution standards, it can provide an important source of justification for teaching evolution (Donnelly and Boone 2007; Dotger et al. 2010)

- Supporting documents - Teachers should become aware of other supporting documents such as position statements from professional organizations (for example, National Association of Biology Teachers and National Science Teachers Association), which provide strong rationales for teaching evolution

In addition to these support mechanisms, teacher educators can draw upon the literature on conflict resolution to help teachers think about dealing with upset parents, administrators, or community patrons. For example, when confronting someone who is upset or angry, it is important to maintain eye contact, keep a low tone of voice, clarify the person's concerns, and provide justifications in a confident manner (Brunner and Lewis 2007; Wellington
1999). It would be helpful for teachers to engage in role-plays of simulated parent-teacher conferences and other potential interactions in which they practice defending the teaching of evolution using these strategies (Dotger et al. 2010).

\section{Goal \#5: pedagogical content knowledge}

A few studies indicate that teachers lack knowledge for teaching evolution (Marcelos and Nagem 2011; van Dijk 2009). The most neglected area of teacher preparation is PCK, as we found no examples in which PCK was an explicit goal for preparing teachers to teach evolution. Even if teachers develop robust understandings of evolution and accept it as scientifically valid, research suggests it will not be sufficient for making it comprehensible for students (Abell 2007). Based upon Magnusson et al. (1999) model of PCK, teachers should develop knowledge for teaching evolution in the following categories:

- Knowledge of Curriculum - includes knowledge of the content goals to be addressed at particular grade levels, as well as the K-12 vertical alignment of evolution goals and ways in which evolution connects to other topics in the horizontal curriculum. Teachers will need to become familiar with the local, state, or national standards that guide the curriculum. It would be helpful for teachers to understand how the standards develop through the $\mathrm{K}-12$ vertical curriculum. For example, in the framework for the recently proposed Next Generation Science Standards in the U.S. (National Research Council 2011), students are expected to understand that some organisms are better suited to their environments than others by the end of grade 5. Students then become introduced to the concept of natural selection by the end of grade 8. Despite the fundamental nature of evolution to the discipline of biology (Zimmer 2010), many teachers do not report viewing or teaching evolution as a unifying theme (Berkman et al. 2008; Weld and McNew 1999). Therefore, we also recommend an increased focus on helping teachers understand and be able to articulate how evolutionary theory explains, incorporates, or connects to other topics across the horizontal curriculum

- Knowledge of Assessment - includes knowledge of assessments specifically designed to reveal students' conceptions of evolution. For example, Anderson and Fisher (2002) developed many concept cartoons, in which a question is asked and cartoon characters provide different responses. Aside from the correct answer, the incorrect answers are based on common student misconceptions. Another assessment is an instrument called the Conceptual 
Inventory of Natural Selection (CINS), developed by Anderson et al. (2002). This instrument could be used at the beginning, middle, and end of the unit to track students' understanding and inform future instructional decisions

- Knowledge of Learners - includes knowledge of student difficulties with the topic. In the case of evolution, this could involve students thinking evolution is based on the organism's need to survive (Anderson et al. 2002), a goal-directed view of evolution (Settlage 1994), or misunderstandings about the nature of scientific theories (Sandoval and Morrison 2003). Thus, common misconceptions derived from the research literature should be explored when preparing teachers to teach evolution

- Knowledge of Instructional Strategies - includes knowledge of specific resources and strategies for teaching evolution. The practitioner literature is replete with interactive activities to teach evolution, including class simulations in which students act as predators and 'hunt' organisms over multiple generations (Sickel and Friedrichsen 2012; National Academy of Sciences 1998; Tieman and Haxer 2007), analyze data from finch populations in the Galapagos Islands (DeFina 2002), track changes in populations using mathematical models (Winterer 2001), and use phylogenetic analysis to determine the relatedness of different groups of animals (Franklin 2010). Wei et al. (2012) discuss the multiple websites available that specifically target evolution instruction, including the Understanding Evolution website (University of California - Berkeley 2012), and the National Institute of Health (National Institute of Health 2012).

Moreover, the Public Broadcasting System website has videos of experienced teachers teaching evolution that can be viewed for professional development (Public Broadcasting System 2012)

We recommend that teachers not only gain access to the instructional resources mentioned above, but also use them to practice planning and teaching lessons. In doing so, teachers will begin to make connections across the knowledge bases and construct specialized, topicspecific knowledge for teaching evolution.

\section{Implementing the goals in teacher preparation and professional development programs}

We have presented five goals for preparing teachers to teach evolution. However, the question of how to implement these goals during teacher preparation programs remains unclear. We believe one option is the development of a course for preservice teachers specific to evolution education. Throughout our review of empirical studies on K-12 teachers, it became apparent that evolution courses have mixed results on teachers' knowledge, beliefs, and practice. Some studies have documented positive correlations between evolution coursework and willingness or advocacy for teaching evolution (Aguillard 1999; Berkman and Plutzer 2011), while other studies report no significant differences (Nehm and Schonfeld 2007; Nehm et al. 2009). As several studies did not explain the nature of the evolution course, it is difficult to know the factors that explain these varied results. However, we conjecture that most evolution courses focus solely on evolution content knowledge. While content knowledge is an important goal for preparing teachers, research indicates that it has a weak association with acceptance (Nehm et al. 2009; Southerland and Sinatra 2003), which is an important predictor for willingness to teach evolution in the classroom (Berkman et al. 2008, Rutledge and Mitchell 2002; Trani 2004). We therefore recommend that teacher preparation programs develop an evolution education course that integrates the five goals listed above. We envision that such a course could potentially be cotaught by a biologist and science educator, and would be required for middle school and secondary biology education majors. This course would integrate content and pedagogy similar to content courses for elementary education majors (Weld and Funk 2005).

Acknowledging that new course development and changes to course requirements in college programs are challenging, another option would be to integrate the five goals throughout science methods courses (Scharmann et al. 2005), graduate courses (Nehm and Schonfeld 2007), or through professional development programs aimed specifically at evolution education (Schrein et al. 2009). In particular, more professional development for elementary teachers is warranted given that they are more likely to reject evolution and possess misunderstandings. We believe the five goals could be implemented during professional development programs in similar ways to the preservice course, and adapted to particular grade ranges. Drawing on the five goals and going beyond content knowledge has the potential to give K-12 teachers a solid foundation for feeling more confident in teaching evolution as well as the practical knowledge to teach it effectively.

\section{Directions for future research}

Our review of the empirical literature on $\mathrm{K}-12$ teachers and evolution education resulted in several questions for future research, primarily in the areas of teacher acceptance and PCK for teaching evolution. Regarding acceptance, research has indicated that understanding of evolution and acceptance of evolution are weakly associated, if at all (Southerland and Sinatra 2003; Nehm et al. 2009). However, Nadelson and Southerland (2010) conducted a study in which they specifically targeted biology students' 
understanding of macroevolution, and found a correlation between understanding and acceptance. Since measures of acceptance tend to focus on macroevolution ideas (descent from common ancestry, deep time), this finding is logical, and supports an increased focus on understanding macroevolution in teacher preparation. Continued research in this area, both with students and teachers, would be helpful. In addition, a potential problem with using measures of acceptance such as the MATE (Rutledge and Warden 1999) is that they include both items about personal understandings of evolution ('the age of the Earth is less than 20,000 years') as well as items about acceptance of evolution as valid within the scientific community ('evolution is a scientifically valid theory'). Therefore, the total MATE score combines these two constructs. We argue that acceptance of evolution as valid within the scientific community should be the primary goal in evolution education, and therefore it needs to be isolated when studying teacher acceptance. Specifically, does acceptance of evolution as a valid scientific theory correlate to increased instructional time for evolution in the curriculum and/or willingness to teach macroevolution in addition to microevolution? Answering this question will provide important implications for preparing teachers to teach evolution.

The second area that needs to be further researched is teachers' PCK for teaching evolution. Even if teachers understand, accept, and are willing to teach evolution, we know very little about how they teach evolution in the classroom. There are many questions to be investigated in this area. What is the nature of beginning teachers' PCK? How does an evolution course with the five goals we present in this paper influence teachers' PCK, if at all? How does teachers' PCK and practice of teaching evolution improve student understanding? Analyzing the nature of teachers' PCK in the classroom will require more indepth case studies with multiple data sources, including classroom observations, interviews, and artifacts such as lesson materials, teacher reflections, and student work. Studies such as these will provide more specific indicators for how teacher knowledge is developing, what facilitates or constrains that development, and the extent to which teachers are helping students understand evolution.

\section{Conclusions}

In this paper, we synthesized the empirical findings on K-12 teachers regarding evolution education. We then used the findings to develop five goals for preparing teachers to teach evolution: (1) develop content knowledge of evolution; (2) develop understandings of the nature of science related to evolution; (3) develop acceptance of evolution as valid within science; (4) develop knowledge of and strategies for handling the public controversy; and (5) develop pedagogical content knowledge for teaching evolution. We recommended that the five goals become integrated in evolution courses during preservice teacher preparation programs and inservice teacher professional development initiatives. Last, we recommended directions for future research, including studies that examine the implementation of the five goals and their influence on teacher development and ultimately student learning. We are hopeful that articulating current findings, goals for teacher preparation based upon those findings, and future research avenues can serve as a starting point for improving teacher preparation, which in turn will improve students' understandings of evolution.

\section{Additional file}

Additional file 1: Appendix A. Summary of 52 articles included in

the review.

\section{Competing interests}

The authors declare that they have no competing interests.

\section{Authors' contributions}

AJS conducted the literature review and summarized the 52 articles. AJS and PF identified the themes of research, and developed the goals for teacher preparation and directions for future research. Both authors read and approved the final manuscript.

\section{Acknowledgements}

This material is based upon work supported by the National Science Foundation Teacher Professional Continuum (TPC) program under Grant 0202847 and the Transforming Undergraduate Education in Science (TUES) program under Grant 1140462. Any opinions, findings, and conclusions or recommendations expressed in this material are those of the author(s) and do not necessarily reflect the views of the National Science Foundation.

\section{Author details}

'Department of Teacher Education, Ohio University, 250 McCracken Hall, Athens, OH 45701, USA. ${ }^{2}$ MU Science Education Center, University of Missouri, 321E Townsend Hall, Columbia, MO 65211, USA.

Received: 21 February 2013 Accepted: 28 May 2013

Published: 5 July 2013

\section{References}

Abell, SK (2007). Research on science teacher knowledge. In SK Abell \& NG Lederman (Eds.), Handbook of research on science education (pp. 1105-1149). New York: Routledge.

Abrie, AL (2010). Student teachers' attitudes toward and willingness to teach evolution in a changing South African environment. Journal of Biological Education, 44(3), 102-107.

Aguillard, D (1999). Evolution education in Louisiana public schools: a decade following Edwards v Aguillard. The American Biology Teacher, 61(3), 182-188. American Association for the Advancement of Science (AAAS). (1993). Benchmarks for science literacy. New York: Oxford University Press. American Association for the Advancement of Science (AAAS). (2001). Atlas of Science Literacy. Washington, DC: Kessler Design Group.

Anderson, D \& Fisher, K (2002). Concept cartoons about evolution. http://www. tncurriculumcenter.org/resource/3205/go. Accessed 1 March 2012.

Anderson, DL, Fisher, KM, \& Norman, GJ (2002). Development and evaluation of the conceptual inventory of natural selection. Journal of Research in Science Teaching, 39(10), 952-978.

Arnold, FH (2008). The race for new biofuels. Engineering and Science, 71(2), 12-19.

Asghar, A, Wiles, JR, \& Alters, B (2007). Canadian pre-service elementary teachers' conceptions of biological evolution and evolution education. McGill Journal of Education, 42(2), 189-209.

Berkman, MB, \& Plutzer, E (2011). Defending evolution in the courtroom, but not in the classroom. Science, 331, 404-405. 
Berkman, MB, Pacheco, JS, \& Plutzer, E (2008). Evolution and creationism in America's classrooms: a national portrait. PLoS Biology, 6(5), 920-924.

BouJaoude, S, Asghar, A, Wiles, JR, Jaber, L, Sarieddine, D, \& Alters, B. (2011). Biology professors' and teachers' positions regarding biological evolution and evolution education in a Middle Eastern society. International Journal of Science Education, 33(7), 979-1000.

Brunner, J, \& Lewis, D (2007). De-escalating an angry conversation. Principal Leadership, 7(7), 62-63.

Catley, KM, \& Novick, LR (2009). Digging deep: exploring college students' knowledge of macroevolutionary time. Journal of Research in Science Teaching, 46(3), 311-332.

Catley, K, Lehrer, R, \& Reiser, B (2005). Tracing a prospective learning progression for 1273 developing understanding of evolution. Paper commissioned by the National 1274 Academies Committee for Test Design on K-12 Science Achievement. Washington, DC National Academy of Sciences.

Cleaves, A, \& Toplis, R. (2007). In the shadow of intelligent design: the teaching of evolution. Journal of Biological Education, 42(1), 30-35.

Crawford, BA, Zembal-Saul, C, Munford, D, \& Friedrichsen, P. (2005). Confronting prospective teachers' ideas of evolution and scientific inquiry using technology and inquiry-based tasks. Journal of Research in Science Teaching, 42(6), 613-637.

Dagher, ZR, \& Boujaoude, S (2005). Students' perceptions of the nature of evolutionary theory. Science Education, 89(3), 378-391.

DeFina, AV (2002). Investigating island evolution: a Galapagos-based lesson using the 5E instructional model. The American Biology Teacher, 69(2), 29-33.

Deniz, H, Donnelly, LA, \& Yilmaz, I. (2008). Exploring factors related to acceptance of evolutionary theory among Turkish preservice biology teachers: toward a more informative conceptual ecology for biological evolution. Journal of Research in Science Teaching, 45(4), 420-433.

Dodick, J, Dayan, A, \& Orion, N. (2010). Philosophical approaches of religious Jewish science teachers toward the teaching of "controversial" topics in science. International Journal of Science Education, 32(11), 1521-1548.

Donnelly, LA, \& Boone, WJ. (2007). Biology teachers' attitudes toward and use of Indiana's evolution standards. Journal of Research in Science Teaching, 44(2), 236-257.

Dotger, S, Dotger, BH, \& Tillotson, J. (2010). Examining how preservice science teachers navigate simulated parent-teacher conversations on evolution and intelligent design. Science Education, 94(3), 552-570.

Evans, EM (2008). Conceptual change and evolutionary biology: A developmental analysis. In S Vosniadou (Ed.), International handbook of research on conceptual change (pp. 263-294). New York: Routledge.

Evans, EM, Legare, C, \& Rosengren, K (2011). Engaging multiple epistemologies: Implications for science education. In M Ferrari \& R Taylor (Eds.), Epistemology and science education: Understanding the evolution vs. intelligent design controversy (pp. 111-139). New York: Routledge.

Fowler, SR, \& Meisels, GG. (2010). Florida teachers' attitudes about teaching evolution. The American Biology Teacher, 72(2), 96-99.

Franklin, WA. (2010). Evolution \& phylogenetic analysis: classroom activities for investigating molecular \& morphological concepts. The American Biology Teacher, 72(2), 114-121.

Freeman, S, \& Herron, JC (2001). Evolutionary analysis (2nd ed.). Upper Saddle River, NJ: Prentice Hall.

Goldhaber, D, \& Anthony, E. (2003). Teacher quality and student achievement. New York, NY: ERIC Clearinghouse on Urban Education.

Goldston, MJ, \& Kyzer, P. (2009). Teaching evolution: narratives with a view from three southern biology teachers in the USA. Journal of Research in Science Teaching, 46(7), 762-790.

Good, RG, Trowbridge, JE, Demastes, SS, Wandersee, JH, Hafner, MS, \& Cummins, CL (Eds.) (1992). Proceedings of the 1992 evolution education research conference. Baton Rouge, LA: Louisiana State University.

Greene, ED, Jr. (1990). The logic of university students' misunderstanding of natural selection. Journal of Research in Science Teaching, 27(9), 875-885.

Griffith, JA, \& Brem, SK. (2004). Teaching evolutionary biology: pressures, stress, and coping. Journal of Research in Science Teaching, 41(8), 791-809.

Hahn, D, Brem, SK, \& Semken, S. (2005). Exploring the social, moral, and temporal qualities of pre-service teachers' narratives of evolution. Journal of Geoscience Education, 53(4), 456-461.

Hatch, JA (2002). Doing qualitative research in education settings. Albany: State University of New York.

Hermann, RS. (2008). Evolution as a controversial issue: A review of instructional approaches. Science Education, 17(8-9), 1011-1032.
Jackson, DF, Doster, EC, Meadows, L, \& Wood, T. (1995). Hearts and minds in the science classroom: the education of a confirmed evolutionist. Journal of Research in Science Teaching, 32(6), 585-611.

Jimenez-Aleixandre, MP. (1994). Teaching evolution and natural selection: a look at textbooks and teachers. Journal of Research in Science Teaching, 31(5), 519-535.

Kim, SY, \& Nehm, RH. (2011). A cross-cultural comparison of Korean and American science teachers' views of evolution and the nature of science. International Journal of Science Education, 33(2), 197-227.

Kose, EO. (2010). Biology students' and teachers' religious beliefs and attitudes towards theory of evolution. H. U. Journal of Education, 38, 189-200.

Lederman, NG, Abd-El-Khalick, F, Bell, RL, \& Schwartz, RS. (2002). Views of nature of science questionnaire: toward valid and meaningful assessment of learners' conceptions of nature of science. Journal of Research in Science Teaching, 39(6), 497-521.

Lenormand, T, Bourguet, D, Guillemaud, T, \& Raymond, M. (1999). Tracking the evolution of insecticide resistance in the mosquito Culex pipiens. Nature, $400,861-864$

Levesque, PJ, \& Guillaume, AM. (2010). Teachers, evolution, and religion: no resolution in sight. Review of Religious Research, 51(4), 349-365.

Losh, SC, \& Nzekwe, B. (2011a). Creatures in the classroom: preservice teacher beliefs about fantastic beasts, magic, extraterrestrials, evolution and creationism. Science Education, 20(5-6), 473-489.

Losh, SC, \& Nzekwe, B. (2011b). The influence of education major: how diverse preservice teachers view pseudoscientific topics. Journal of Science Education and Technology, 20(5), 579-591.

Magnusson, S, Krajcik, J, \& Borko, H (1999). Nature, sources and development of pedagogical content knowledge for science teaching. In J Gess-Newsome \& NG Lederman (Eds.), Examining pedagogical content knowledge (pp. 95-132). Dordrecht, The Netherlands: Kluwer Academic Publishers.

Marcelos, MF, \& Nagem, RL. (2011). Use of the "tree" analogy in evolution teaching by biology teachers. Science Education, 21(4), 507-541.

McCrory, C, \& Murphy, C. (2009). The growing visibility of creationism in Northern Ireland: are new science teachers equipped to deal with the issues? Evolution: Education \& Outreach, 2(3), 372-385.

Meadows, L, Doster, E, \& Jackson, DF. (2000). Managing the conflict between evolution and religion. The American Biology Teacher, 62(2), 102-107.

Moore, R. (2004). How well do biology teachers understand the legal issues associated with the teaching of evolution? Bioscience, 54(9), 860-865.

Moore, R. (2007). The differing perceptions of teachers \& students regarding teachers' emphasis on evolution in high school biology classrooms. The American Biology Teacher, 69(5), 268-271.

Moore, R, \& Kraemer, K. (2005). The teaching of evolution and creationism in Minnesota. The American Biology Teacher, 67(8), 457-466.

Moore, R, Mitchell, G, Bally, R, Inglis, M, Day, J, \& Jacobs, D. (2002). Undergraduates' understanding of evolution: ascriptions of agency a problem for student learning. Journal of Biological Education, 36(2), 65-71.

Moore, R, Brooks, CD, \& Cotner, S. (2011). The relation of high school biology courses \& students' religious beliefs to college students' knowledge of evolution. The American Biology Teacher, 73(4), 222-226.

Nadelson, LS. (2009). Preservice teacher understanding and vision of how to teach biological evolution. Evolution: Education \& Outreach, 2(3), 490-504.

Nadelson, LS, \& Southerland, SA. (2010). Development and preliminary evaluation of the measure of understanding of macroevolution: introducing the MUM. The Journal of Experimental Education, 78(2), 151-190.

National Academy of Sciences (1998). Teaching about evolution and the nature of science. Washington, DC: National Academy Press.

National Institute of Health (2012). NIH curriculum supplement on evolution and medicine for grades 9-12. http://science-education.nih.gov/customers.nsf. Accessed 1 March 2012.

National Research Council. (1996). National science education standards. Washington, DC: National Academy Press.

National Research Council (2001). Educating teachers of science, mathematics, and technology: New practices for the new millennium. Washington, DC: National Academy Press.

National Research Council (2011). A framework for K-12 science education: Practices, cross-cutting concepts, and core ideas. Washington, DC: National Academies Press.

Nehm, RH, \& Schonfeld, IS. (2007). Does increasing biology teacher knowledge of evolution and the nature of science lead to greater preference for the teaching of evolution in schools? Journal of Science Teacher Education, 18(5), 699-723. 
Nehm, RH, Kim, SY, \& Sheppard, K. (2009). Academic preparation in biology and advocacy for teaching evolution: biology versus non-biology teachers. Science Education, 93(6), 1122-1146.

Oliveira, AW, Cook, K, \& Buck, GA. (2011). Framing evolution discussion intelligently. Journal of Research in Science Teaching, 48(3), 257-280.

Osif, BA. (1997). Evolution \& religious beliefs: a survey of Pennsylvania high school teachers. The American Biology Teacher, 59(9), 552-556.

Public Broadcasting System. (2012). PBS evolution. www.pbs.org/wgbh/evolution Accessed 5 March 2012.

Reiser, BJ, Tabak, I, Sandoval, WA, Smith, BK, Steinmuller, F, \& Leone, AJ. (2001). BGulLE: Strategic and conceptual scaffolds for scientific inquiry in biology classrooms. In S.M. Carver \& D. Klahr (Eds.), Cognition and instruction: Twenty-five years of progress (pp. 263-305). Mahwah, NJ: Erlbaum.

Rudolph, J, \& Stewart, J. (1998). Evolution and the nature of science: on the historical discord and its implications for education. Journal of Research in Science Teaching, 35(10), 1069-1089.

Rutledge, ML, \& Mitchell, MA. (2002). Knowledge structure, acceptance, \& teaching of evolution. The American Biology Teacher, 64(1), 21-28.

Rutledge, ML, \& Warden, MA. (1999). The development and validation of the measure of acceptance of evolutionary theory instrument. School Science and Mathematics, 99(1), 13-18.

Rutledge, ML, \& Warden, MA. (2000). Evolutionary theory, the nature of science \& high school biology teachers: critical relationships. The American Biology Teacher, 62(1), 23-31.

Sanders, M, \& Ngxola, N. (2009). Identifying teachers' concerns about teaching evolution. Journal of Biological Education, 43(3), 121-128.

Sandoval, WA, \& Morrison, K. (2003). High school students' ideas about theory and theory change after a biological inquiry unit. Journal of Research in Science Teaching, 40(4), 369-392.

Scharmann, LC. (1990). Enhancing an understanding of the premises of evolutionary theory: the influence of a diversified instructional strategy. School Science and Mathematics, 90(2), 91-100.

Scharmann, LC. (1994). Teaching evolution: the influence of peer teachers instructional modeling. Journal of Science Teacher Education, 5(2), 66-76.

Scharmann, LC, Smith, MU, James, MC, \& Jensen, M. (2005). Explicit reflective nature of science instruction: evolution, intelligent design, and umbrellaology. Journal of Science Teacher Education, 16(1), 27-41.

Schilders, M, Sloep, P, Peled, E, \& Boersma, K. (2009). Worldviews and evolution in the biology classroom. Journal of Biological Education, 43(3), 115-120.

Schrein, CM, Lynch, JM, Brem, SK, Marchant, GE, Schedler, KK, Spencer, MA, Kazilek, CJ, \& Coulombe, MG. (2009). Preparing teachers to prepare students for post-secondary science: observations from a workshop about evolution in the classroom. Journal of Effective Teaching, 9(2), 69-80.

Schulteis, MW. (2010). Education's missing link: how private school teachers approach evolution. The American Biology Teacher, 72(2), 91-94.

Scott, EC. (1997). Antievolution and creationism in the United States. Annual Review of Anthropology, 26, 263-289.

Settlage, J. (1994). Conceptions of natural selection: a snapshot of the sense-making process. Journal of Research in Science Teaching, 31(5), 449-457.

Shankar, G, \& Skoog, GD. (1993). Emphasis given evolution and creationism by Texas high school biology teachers. Science Education, 77(2), 221-233.

Sickel, AJ, \& Friedrichsen, PM. (2012). Using the FAR guide to teach simulations: an example with natural selection. The American Biology Teacher, 74(1), 47-51.

Simberloff, D, \& Stiling, P. (1996). How risky is biological control? Ecology, 77(7), 1965-1974.

Smith, MU, \& Scharmann, L. (2008). A multi-year program developing an explicit reflective pedagogy for teaching pre-service teachers the nature of science by ostention. Science Education, 17(2-3), 219-248.

Smith, MU, \& Siegel, H. (2004). Knowing, believing, and understanding: what goals for science education? Science Education, 13(6), 553-582.

Southerland, SA. (2000). Epistemic universalism and the shortcomings of curricular multicultural science education. Science Education, 9(3), 289-307.

Southerland, SA, \& Sinatra, GM (2003). Learning about biological evolution: A special case of intentional conceptual change. In GM Sinatra \& PR Pintrich (Eds.), Intentional conceptual change (pp. 317-345). Mahwah, New Jersey: Lawrence Erlbaum Associates.

Tidon, R, \& Lewontin, RC. (2004). Teaching evolutionary biology. Genetics and Molecular Biology, 27(1), 124-131.

Tieman, D, \& Haxer, G. (2007). The discovery of jelly bellicus: using jelly beans to explore natural selection. The Science Teacher, 74(2), 30-35.
Tomczyk, J, \& Bugajak, G. (2009). Education on religion-and-science attitudes and ideas. Zygon, 44(4), 859-878.

Trani, R. (2004). I won't teach evolution; it's against my religion: and now for the rest of the story. The American Biology Teacher, 66(6), 419-427.

Trefil, J, \& Obrien-Trefil, W. (2009). The science students need to know. Educational Leadership, 67(1), 28-33.

University of California - Berkeley (2012). Understanding evolution. http://evolution. berkeley.edu. Accessed 5 March 2012.

van Dijk, EM. (2009). Teachers' views on understanding evolutionary theory: a PCK-study in the framework of the ERTE-model. Teaching and Teacher Education, 25(2), 259-267.

Veal, WR, \& Kubasko, DS, Jr. (2003). Biology and geology teachers' domain-specific pedagogical content knowledge of evolution. Journal of Curriculum and Supervision, 18(4), 334-352.

Vlaardingerbroek, B, \& Roederer, CJ. (1997). Evolution education in Papa New Guinea: trainee teachers' views. Educational Studies, 23(3), 363-375.

Wei, CA, Beardsley, PM, \& Labov, JB. (2012). Evolution education across the life sciences: making biology education make sense. CBE Life Sciences Education, $11(1), 10-16$

Weld, J, \& Funk, L. (2005). "I'm not the science type": effect of an inquiry biology content course on preservice elementary teachers' intentions about teaching science. Journal of Science Teacher Education, 16(3), 189-204.

Weld, J, \& McNew, JC. (1999). Attitudes toward evolution. The Science Teacher, 66(9), 27-31.

Wellington, S. (1999). Parent-teacher relationships. Child Education, 76, 49.

Winslow, MW, Staver, JR, \& Scharmann, LC. (2011). Evolution and personal religious belief: Christian university biology-related majors' search for reconciliation. Journal of Research in Science Teaching, 48(9), 1026-1049.

Winterer, J. (2001). A lab exercise explaining Hardy-Weinberg equilibrium and evolution effectively. The American Biology Teacher, 63(9), 678-687.

Zimmer, C. (2001). Genetic trees reveal disease origins. Science, 292(5519), 1090-1093.

Zimmer, C (2010). The tangled bank: An introduction to evolution. Greenwood Village, CO: Roberts and Company.

Zuzovsky, R. (1994). Conceptualizing a teaching experience on the development of the idea of evolution: An epistemological approach to the education of science teachers. Journal of Research in Science Teaching, 31(5), 557-574.

\section{doi:10.1186/1936-6434-6-23}

Cite this article as: Sickel and Friedrichsen: Examining the evolution education literature with a focus on teachers: major findings, goals for teacher preparation, and directions for future research. Evolution: Education and Outreach 2013 6:23.

\section{Submit your manuscript to a SpringerOpen ${ }^{\circ}$ journal and benefit from:}

- Convenient online submission

- Rigorous peer review

- Immediate publication on acceptance

- Open access: articles freely available online

- High visibility within the field

- Retaining the copyright to your article

Submit your next manuscript at springeropen.com 